Original Research Paper

\title{
The Impact of Chernozem Contamination with Lead and Oil on the Abundance and Composition of Microarthropods
}

\author{
Sergey Ilyich Kolesnikov, Lidiya Sergeevna Samokhvalova, \\ Maria Gennadievna Zharkova, Kamil Shagidullovich Kazeev and Yuliya Viktorovna Akimenko \\ Academy of Biology and Biotechnology, Southern Federal University, \\ 344006, Russia, Rostov-on-Don, Bolshaya Sadovaya Str., 105/42, Russia
}

Article history

Received: 04-12-2014

Revised: 26-02-2015

Accepted: 28-02-2015

Corresponding Author: Sergey Ilyich Kolesnikov Southern Federal University, Academy of Biology and Biotechnology, 344006, Russia, Rostov-on-Don, Bolshaya Sadovaya Str., 105/42, Russia Email: Kolesnikov@sfedu.ru

\begin{abstract}
Micro arthropods population reduced with increase in the amount of oil in chernozem. The same pattern was observed up to a certain concentration of lead in the soil (background $+250 \mathrm{mg} \mathrm{kg}^{-1}$ ) and then at high doses $\left(+500\right.$ and $\left.+1000 \quad \mathrm{mg} \mathrm{kg} \mathrm{kg}^{-1}\right)$ an increase in microarthropods abundance was recorded. Gamazid mites and acaroidtrombidi form complex mites proved to be more resistant to contamination with lead and on the contrary armored mites and springtails proved to be more resistant to contamination with oil.
\end{abstract}

Keywords: Chernozem, Contamination, Oil, Lead, Microarthropods

\section{Introduction}

Soil microarthropods due to their features (high mortality and rapid abundance build-up) sensitively and quickly respond to changes in hydro-thermic and chemical composition of the soil. This makes them good indicators of soil condition (Chernova, 1981; Gilyarov, 1965; Gilyarov and Striganova, 1978; Gilyarov, 1982; Kazadaev et al., 2008; Petersen and Luxton, 1982; Striganova, 1980).

In this study we study the impact of ordinary chernozem contamination with lead and oil on the abundance of soil microarthropods.

\section{Objects and Methods}

Field model experiments were carried out in ordinary chernozem (North-Azov) in the Botanical Garden of the Southern Federal University (Rostov-on-Don). The width of the chernozemhumus horizon is $80 \mathrm{~cm}$, the grain size composition is heavy loamy, the medium reaction is 7.7 , humus content is $4.1 \%$.

Plot areas of $1 \mathrm{~m}^{2}$ were laid with distances between them of $0.5 \mathrm{~m}$. The replication was triple.

Lead was introduced into the soil at doses of 25, 50, $100,250,500$ and $1000 \mathrm{mg} \mathrm{kg}$. Background lead content in the soil is $15.3 \mathrm{mg} \mathrm{kg}$. Maximum Permissible Concentration (MPC) of lead in the soil is $32 \mathrm{mg} \mathrm{kg}^{-1}$ in Russia (Agropromizdat, 1991). Lead oxide (II)-PbO was used. Soil contamination with lead in $70-90 \%$ occurs in the form of oxides (Gorbatov, 1988).
Oil was added into the soil at doses of $0.25 ; 0.5 ; 1.0$; $2.5 ; 5.0 ; 10.0 \%$ of soil weight. Oil MPC in the soil is not determined yet. The oil used in the research is characterized by average density of $(0.8616$ $\left.\mathrm{kg} / \mathrm{m}^{3}\right)$, average sulfur content of $(1.34 \%)$ and chloride salts content of $\left(73.0 \mathrm{mg} / \mathrm{dm}^{3}\right)$, low solids content of $(0.0060 \%)$ and wax mass fraction content of $4.46 \%$.

Since lead oxide is insoluble in water, for uniform distribution in the soil, it was first triturated with small amount of the soil in a mortar and then mixed with a large amount of the soil in the basin and then maximally evenly distributed in the upper layer of the soil $(0-20 \mathrm{~cm})$ plots by digging. Oil was added to the surface by method of sprinkling.

Experimental plots were laid in August. In a month they were planted with winter wheat (Donchanka variety). Microarthropod abundance was determined by the generally accepted method (Gilyarov, 1965). Soil samples were taken three times during May-June of the following year (after 270 days after soil contamination) from the upper layer of $0-20 \mathrm{~cm}$. In each plot 5 mixed soil samples were taken with a metal frame of $125 \mathrm{~cm}^{3}$ volume. In total 15 soil samples were selected from each plot.

The extraction of soil microarthropod was performed on eclectors under natural light without electrical heating for 7 days up to complete drying, followed by storage in $70 \%$ alcohol with added glycerol. During manual dismantling of samples under a binocular microscope MBS-10 microarthropod composition was detected: 
Armored mites belonging to Acariformer order, Sarcoptiformes suborder; Gamasid mites belonging to Parasitiformer order, Mesostigmata suborder. Mites belonging to Trombidiformes suborder (tarsonemoid, endeostigmatic, prostigmatic) and Acariformes mites of Sarcoptiformes suborder were combined in Acaroidtrombidiform complex. Other animals by their small dimensions werereferred to other invertebrates.

\section{Results}

The data obtained (Table 1 and 2) shows considerable variation, which makes it impossible to make reliable conclusions about the impact of pollutants on the microartropods. At the same time, we can point out statistically unconfirmed, but rather pronounced tendencies.

During ordinary chernozem contamination with oil there is a decrease in the number of microarthropods while increasing the amount of the pollutant in the soil compared with controls (Table 1), which is quite natural and expected. However, the abundance variability of different groups of microarthropods had certain specific features.

In the control plot the maximum number of mites belonged to acaroid-trombidiform complex and gamasid mites. At the same time their abundance in all experiment plots $(0.25-10 \%)$ decreased as the oil concentration increased, but even in the plot with the highest concentration $(10 \%)$ the abundance indices of these groups of microarthropods remained above others (armored mites, springtails) suggesting a greater resistance to soil contamination with oil.

The abundance of armored mites in the area with minimal contamination $(0.25 \%)$ prevailed over the control group (1.1 and 0.7 thousand ind. $/ \mathrm{m}^{2}$, respectively), but with the rise in oil concentration, their abundance decreased.

The abundance of springtails naturally decreases with the rise in oil concentration $(0.25-10 \%)$ and initially was lower than the springtails abundance of control plot (Table 1).

In areas with high concentration of oil $(5-10 \%)$, the number of all groups of micro artropods significantly decreased compared with lower concentrations $(0.25-2.5 \%)$ and control. The minimum number was registered for armored mites and springtails $\left(0.04\right.$ thousand ind $\left./ \mathrm{m}^{2}\right)$ in comparison with other groups of microarthropods.

In ordinary chernozem contamination with lead there is a downward trend in the abundance of microarthropods up to a certain concentration of metal in the soil (background $+250 \mathrm{mg} \mathrm{kg}{ }^{-1}$ ). With increasing doses of pollutant (500 and $1000 \mathrm{mg} \mathrm{kg}$ ) there was some increase in the abundance of separate groups of microarthropods (except springtails) (Table 2).

In the control plot the maximum number belonged to armored mites and acaroid-trombidiform complex mites (2.3 and 7.9 thousand ind. $/ \mathrm{m}^{2}$, respectively), while minimum belonged to gamasid mites (1.3 thousand ind. $/ \mathrm{m}^{2}$ ). With small doses of contamination the abundance of armored and gamasid mites is first reduced, while at higher doses $\left(250,500,1000 \mathrm{mg} \mathrm{kg}^{-1}\right)$ it started to rise.

The number of acaroid-trombidi form complex mites showed interesting, but irregulardynamics: Increasing the dose of lead caused a decrease in the number of mites $(25$, $\left.100,250 \mathrm{mg} \mathrm{kg}^{-1}\right)$ and an increase in their numbers (50, $500,1000 \mathrm{mg} \mathrm{kg}^{-1}$ ) compared to the control because it is difficult to judge the resistance of this microarthropod group to ordinary chernozemcontamination with lead.

Table 1. The impact of ordinary chernozem contamination with oil on the abundance (thousand ind./ $\mathrm{m}^{2}$ ) of different groups of microarthropods (Botanical Garden of SFedU)

\begin{tabular}{llllll}
\hline Oi lcontent (\%) & Armouredmites & Gamasid mites & Springtails & $\begin{array}{l}\text { Acaroid- } \\
\text { trombidiformcomplexmites }\end{array}$ & Otherinvertebrates \\
\hline Control group & $0,7 \pm 1,3$ & $1,2 \pm 1,2$ & $0,4 \pm 0,9$ & $2,0 \pm 1,4$ & $0,7 \pm 1,1$ \\
0,25 & $1,1 \pm 1,3$ & $0,8 \pm 1,1$ & $0,3 \pm 0,9$ & $1,0 \pm 1,1$ & $0,8 \pm 1,2$ \\
0,5 & $0,6 \pm 1,3$ & $0,7 \pm 1,2$ & $0,4 \pm 1,9$ & $0,8 \pm 1,1$ & $0,8 \pm 1,2$ \\
1,0 & $0,5 \pm 1,3$ & $0,7 \pm 1,2$ & $0,2 \pm 1,9$ & $0,8 \pm 1,1$ & $0,6 \pm 1,2$ \\
2,5 & $0,2 \pm 1,8$ & $0,5 \pm 1,2$ & $0,2 \pm 1,9$ & $0,5 \pm 1,7$ & $0,4 \pm 1,2$ \\
5 & $0,1 \pm 2,7$ & $0,2 \pm 2,1$ & $0,09 \pm 2,3$ & $0,3 \pm 2,0$ & $0,2 \pm 2,2$ \\
10 & $0,04 \pm 2,7$ & $0,1 \pm 2,1$ & $0,04 \pm 2,3$ & $0,2 \pm 2,0$ & $0,1 \pm 1,5$ \\
\hline
\end{tabular}

Table 2. The impact of ordinary chernozem contamination with lead on the abundance (thousand ind. $/ \mathrm{m}^{2}$ ) of different groups of microarthropods (Botanical Garden of SFEDU)

\begin{tabular}{llllll}
\hline Lead content $(\mathrm{mg} / \mathrm{kg})$ & Armouredmites & Gamasid mites & Springtails & $\begin{array}{l}\text { Acaroid- } \\
\text { trombidiformcomplexmites }\end{array}$ & Otherinvertebrates \\
\hline Background & $2,3 \pm 2,1$ & $1,3 \pm 1,1$ & $1,4 \pm 1,0$ & $7,9 \pm 2,0$ & $1,6 \pm 1,3$ \\
+25 & $1,1 \pm 1,2$ & $1,1 \pm 1,0$ & $1,6 \pm 1,3$ & $6,4 \pm 1,2$ & $1,1 \pm 1,0$ \\
+50 & $0,9 \pm 1,4$ & $1,0 \pm 1,2$ & $1,4 \pm 1,0$ & $9,1 \pm 2,0$ & $1,0 \pm 0,9$ \\
+100 & $0,9 \pm 1,1$ & $1,0 \pm 1,2$ & $0,7 \pm 0,9$ & $4,5 \pm 2,2$ & $0,8 \pm 1,1$ \\
+250 & $1,0 \pm 1,6$ & $0,6 \pm 0,8$ & $0,5 \pm 1,1$ & $2,5 \pm 1,8$ & $0,6 \pm 0,9$ \\
+500 & $2,0 \pm 1,3$ & $1,6 \pm 1,2$ & $0,9 \pm 1,3$ & $9,1 \pm 2,0$ & $1,0 \pm 1,1$ \\
+1000 & $2,3 \pm 1,6$ & $1,6 \pm 1,2$ & $1,3 \pm 1,2$ & $9,7 \pm 2,6$ & $1,3 \pm 1,4$ \\
\hline
\end{tabular}


The abundance of springtails in experimental plots decreased with the growth of lead doses and in the area with the highest concentration of pollutant their abundance compared with the abundance of other microarthropod groups was minimal (1.3 thousand ind. $\left./ \mathrm{m}^{2}\right)$.

The abundance of armored mites and other invertebrates (enchytraeids, nematodes, etc.) was higher than the control in the plot with lead contamination dose of $0.25 \mathrm{mg} \mathrm{kg}^{-1}$ (Table 2) and while increasing the concentration of the pollutant $\left(0.5-10 \mathrm{mg} \mathrm{kg}^{-1}\right)$ its decline was registered.

Thus, different groups of microarthropods showed different resistance to lead and oil. According to the degree of resistance to lead contamination the investigated microarthropod groups were ranked as follows: Gamasidmites = acaroid-trombidiform complex mites $>$ springtails $>$ armored mites.

According to the degree of resistance to oil pollution the studied microarthropod groups formed the following series: Armored mites $>$ springtails $>$ gamasid mites $>$ acaroid-trombidiform complex mites.

Interestingly, microarthropod groups which were more tolerant to lead contamination were less resistant to oil and vice versa.

This may be due to differences in the impact patterns of lead and oil on living organisms. The mechanism of the toxic effect of lead is connected with violation of living organisms metabolism as a result of the deterioration of cell membrane permeability and enzyme inhibition (Torshin et al., 1990). The negative impact of oil is to a greater extent indirect and is manifested in the deterioration of the water-air regime of the soil (Trofimov et al., 2000).

\section{Conclusion}

In contamination of chernozem with oil a statistically insignificant, but rather strong tendency was revealed to reduce the abundance of microartropods while increasing the amount of the pollutant in the soil. In lead contamination such tendency was observed up to a certain concentration of the metal in the soil (background $+250 \mathrm{mg} \mathrm{kg}^{-1}$ ) and then at high doses (500 and $1000 \mathrm{mg} \mathrm{kg}^{-1}$ ) an increase in the abundance of micro arthropods was recorded.

Different groups of micro arthropods showed different resistance to lead and oil. According to the degree of resistance to lead contamination the investigated micro arthropod groups were ranked as follows: Gamasid mites = acaroid-trombidiform complex mites $>$ springtails $>$ armored mites. According to the degree of resistance to oil pollution the studied micro arthropod groups formed the following series: Armored mites $>$ springtails $>$ gamasid mites $>$ acaroidtrombidiform complex mites. Microarthropod groups more tolerant to lead contamination were less resistant to the impact of oil and vice versa.

\section{Acknowledgement}

Investigation was supported by the Ministry of Education and Science of the Russian Federation (6.345.2014/K) and by the Leading Scientific Schools program (NSh_2449.2014.4).

\section{Author's Contributions}

All authors equally contributed in this work.

\section{Ethics}

This article is original and contains unpublished material. The corresponding author confirms that all of the other authors have read and approved the manuscript and no ethical issues involved.

\section{References}

Gilyarov, M.S., 1965. Zoological method for the diagnosis of soil.

Gilyarov, M.S., 1982. Soil invertebrates as indicators of soil regime and its changes under the influence of anthropogenic factors. Bioindication Environ. Around Moscow Moscow Region.

Gilyarov, M.S. and B.R. Striganova, 1978. The role of soil animals in decomposition of plant residues and circulation of substances//results of science and technology. Invertebrate Zool.

Kazadaev, A.A., A.M. Kremenitsa, E.I. Simonovich, N.I. Bulysheva and L.S. Vezdeneeva, 2008. Soil fauna and soil fertility. 1st Edn., NMC Logos, pp: 114.

Striganova, B.R., 1980. Food of soil saprophages.

Chernova, N.M., 1981. Dynamics features of microarthropods in arable soils. Problems Soil Zool.

Petersen, H. and M.A. Luxton, 1982. A comparative analysis of soil fauna populations and their role in decomposition processes. Oikos, 39: 287-388. DOI: $10.2307 / 3544689$

Agropromizdat, 1991. Chemical contamination of soils and their protection. Agropromizdat.

Gorbatov, V.S., 1988. Stability and transformation of heavy metal oxides, metals $(\mathrm{Zn}, \mathrm{Pb}, \mathrm{Cd})$ in soils. Soil Sci., 1: 35-43.

Torshin, S.P., T.M. Udelnova and B.A. Yagodyn, 1990. Microelements, ecology and human health. Success Modern Biol. T, 109: 279-292.

Trofimov, S.Y., Y.M. Ammosova, D.S. Orlov, N.N. Osipova and N.I. Sukhanov, 2000. Influence of oil on soil conditions and the problem of creating a regulatory framework for the impact of oil contamination on soil. Moscow University Bulletin, Series 16. Soil Sci. 